\title{
Pecan cultivation: general aspects
}

\author{
Diniz Fronza ${ }^{1}$ Jonas Janner Hamann ${ }^{2}$ Vanderlei Both $^{3 *}$ \\ Rogério de Oliveira Anese ${ }^{4}$ Evandro Alcir Meyer ${ }^{5}$
}

\author{
${ }^{1}$ Colégio Politécnico, Universidade Federal de Santa Maria (UFSM), Santa Maria, RS, Brasil. \\ ${ }^{2}$ Programa de Pós-graduação em Agronomia, Universidade Federal de Santa Maria (UFSM), Santa Maria, RS, Brasil. \\ ${ }^{3}$ Departamento de Fitotecnia, Universidade Federal de Santa Maria (UFSM), Camobi, 97.105-900, Santa Maria, RS, Brasil. E-mail: \\ vanderleiboth@yahoo.com.br. "Corresponding author. \\ ${ }^{4}$ Instituto Federal de Santa Catarina (IFSC), Urupema, SC, Brasil. \\ ${ }^{5}$ Departamento de Ciências Florestais, Universidade Federal de Santa Maria (UFSM), Santa Maria, RS, Brasil.
}

ABSTRACT: Given the increasing investment in the pecan production in southern Brazil, it becomes necessary researches, assisting in solve problems and proposition of technical and methodology to enhance this production chain. Thus, the present review aimed to survey the existing information about the culture, both on the world and the Brazilian scene. Issues related to botany, climate and soil requirements, alignment and planting density, cultivars, pests and diseases, among other technical aspects of this culture will be addressed. Pecan nut presents nutraceutical properties that are beneficial to human health, which has increased its demand from consumers. However, there are few research results with pecan nut in Brazil and there are many gaps in scientific knowledge about this culture, especially as regards the management of pests and diseases control, irrigation and nutrition, in Brazilian conditions.

Key words: Carya illinoinensis (Wangenh.) K. Koch, management, pollination, cultivars.

Pecanicultura: aspectos gerais da cultura

RESUMO: Diante do crescente investimento na cultura da nogueira-pecã no sul do Brasil, torna-se necessário que a pesquisa atue auxiliando na solução de problemas e na proposição de técnicas e metodologia para potencializar esta cadeia produtiva. Desta forma, a presente revisão bibliográfica objetiva realizar um levantamento das informações existentes sobre a cultura, tanto no panorama mundial quanto brasileiro. Serão abordadas questões relacionadas com a botânica, exigências climáticas e edáficas, alinhamento e densidade de plantio, cultivares, pragas e doenças, entre outros aspectos técnicos da cultura. A noz apresenta propriedades nutracêuticas, que são benéficas para a saúde humana, o que tem aumentado a sua procura por parte dos consumidores. No entanto, são poucos os resultados de pesquisa com a cultura da nogueira no país e existem diversas lacunas no conhecimento cientifico sobre o cultivo da nogueira, principalmente, no que diz respeito ao manejo de pragas e doenças, irrigação e nutrição nas condições brasileiras.

Palavras-chave: Carya illinoinensis (Wangenh.) K. Koch, manejo, polinização, cultivares.

\section{INTRODUCTION}

Fruit production assumes a greater importance each year in many regions of Brazil. This occurs due to the diversity of species that can be cultivated in the country's different edaphoclimatic conditions and, mainly, by the changes in the people consumption habits. Presently, people are looking to consume more natural foods, on account of the increase of the population's per capita income, and especially, due to the fruits nutraceutical effects. Among the natural foods, pecans are highlighted for their beneficial health effects, since they have phenolic compounds, mono and polyunsaturated fatty acids, phytosterols, tocopherols and micronutrients that reduce the risk of diseases (DOMÍNGUEZAVILA et al., 2015). According to EAGAPPAN \& SASIKUMAR (2014), a regular consumption of nuts has been associated with several health benefits, protecting from oxidative stress, reducing LDL (bad) cholesterol, beyond their anticancer, antiinflammatory, and antidiabetic benefits, preventing chronic diseases.

The greater importance that fruits are assuming in the population's diet may be verified by the larger physical space available at supermarkets and by the greater variety of horticultural products displayed, providing new opportunities of production 
and income for farmers. However, the success of fruit plants cultivation rely on technical knowledge and understanding the peculiarities of each culture, which are related to soil management, irrigation and the ability to carry out each species according to their special requirements. Many fruit tree species, when cultivated without proper management, present production alternation, smaller and fewer fruits, besides a shorter lifespan.

Fruit plants, unlike annual crops, represent a high initial investment, with a longterm of return. This is more noticeable in pecan cultivation, which starts its production between the $4^{\text {th }}$ and $10^{\text {th }}$ year, but will only reach full production between the $12^{\text {th }}$ and $15^{\text {th }}$ year after planting (WELLS, 2017). Therefore, the diffusion of technical information regarding the management of pecan production is very important in Brazil.

Weather of Southern Brazil presents favorable characteristics for pecan cultivation, and currently, there are a few private companies exploring this possibility, offering seedlings for planting and inputs for orchards management. Moreover, there is a possibility of production expansion, because more than $50 \%$ of the nuts consumption in Brazil are imported (FRONZA \& HAMANN, 2016). Nonetheless, there is very limited scientific information regarding pecan cultivation in this region. Therefore, the aim of this review is to address the global and the Brazilian pecan cultivation, as well as the botanic description, climate and edaphic requirements, planting alignment and density, cultivars, pests and diseases, among other technical aspects concerning this culture.

\section{DEVELOPMENT}

\section{Botanic description}

The pecan [Carya illinoinensis (Wangenh.) $\mathrm{K}$. Koch] is a plant that belongs to Juglandaceae family, native of the lowland of the Mississippi River regions, with deep, fertile and well-drained soils. This area extends from the South of Illinois (USA) to Mexico (SPARKS, 2005). Pecan is a deciduous tree, with alternate leaves, pinnate, up to 45 centimeters in length, composed by nine to 15 leaflets. Monoecious plant, the staminate flowers (male) are called catkins and are arranged in groups of two to eight, each group with three catkins and located on the last season's shoots. The pistillate inflorescences (female) are considered a cluster and appear at the end of the current season's shoots.

The pecan tree is a large plant, with about 20 to 30 meters high, reaching up to 40 meters under adequate conditions, with 12 to 20 meters crown diameter and 2 meters trunk circumference. Its productive period is characterized for lasting longer than a hundred years, producing nuts of great commercial value. The root system consist of a taproot that is generated in the first year. In the second year, lateral roots grow perpendicular to the first and parallel to soil line and develop an anchoring function, especially the ones found closer to surface. From these ones emerge roots that grow vertically and have the function of absorbing water and nutrients (SPARKS, 2005). Fibrous roots grow in all directions from the side and are subject to constant death and replacement as a result of different growth conditions, while the mycorrhizal roots are a type of fibrous roots that grow in dense masses throughout the area explored by roots (BONITO et al., 2011). The area explored by the pecan tree roots can expand up to twice beyond the canopy projection and its growth may be limited by the occurrence of drought, excessive moisture in the subsoil and soil temperature lower to $18^{\circ} \mathrm{C}$ (WELLS, 2017).

\section{Global overview}

The United States are responsible for $55 \%$ and Mexico for $38 \%$ of the pecan nuts world production, which are the main producers (INC, 2015). In the United States, the pecan cultivation is located mainly in the states of Georgia $(48,562 \mathrm{ha})$, Texas (40,468ha), Oklahoma (38,040ha) and New Mexico (16,187ha). Georgia and New Mexico are the states with largest productions (BARRIOS et al., 2010; USDA, 2017). The nuts are consumed in natura or included in the production of foods, like cereals, energy bars and chocolate bars (WAKELING et al., 2001).

Pecan commercial crops are also established in Brazil, Israel, Australia, Peru, South Africa and Argentina (WAKELING et al., 2001; BARRIOS et al., 2010). With the recent development of the Chinese market and its demand for nuts, pecan orchards are being implemented along the coastal area of southern China (ZHANG et al., 2015).

\section{History of pecan in Brazil}

Pecan was introduced in Brazil by North American immigrants in the 1870 s, who established residence in the state of São Paulo, in the town of Santa Bárbara D'Oeste (ORTIZ \& CAMARGO, 2005). According to the authors, the implementation of the first plants had as objective the production of nuts for typical cuisine of these immigrants. The introduction of cultivars with commercial purposed took place in 
1915, by the entrepreneur Mário Veiga de Moraes, who planted a few seedlings from three cultivars in the Canteiro farm, located near Nova Friburgo, in the state of Rio de Janeiro (MURAYAMA, 1986).

In Rio Grande do Sul State, the town of Anta Gorda pioneered the cultivation of pecan in the year of 1943, when the mayor (Armínio Miotto) became aware of this culture through the announcement of a seedling nursery in São Paulo, which marketed seedlings imported from Kentucky, USA. A few seedlings where then acquired, which are still in production in this town (FRONZA \& HAMANN, 2016). The beginning of nut production of these first seedlings aroused the interest of local farmers in this culture. So, the production of pecan seedlings was initiated in this town, since there was no other production or commercialization of this fruit species in the RS State (FRONZA \& HAMANN, 2016).

\section{Brazilian scenario}

In Brazil, pecan commercial crops are found for some decades. A few years ago, the culture underwent a new incentive from investors, and it was in the state of Rio Grande do Sul where the expansion was the most significant (FRONZA \& HAMANN, 2016). The Brazilian harvest of pecan occurs during March to May, which coincide with the off-season in USA and Mexico, where the harvest is carried out from October to December (LÓPEZ et al., 2014).

The harvested area of pecan in Brazil, in 2008, was correspondent to 1,614 hectares, with an average yield of $1,433 \mathrm{~kg} \mathrm{ha}^{-1}$. In 2015, there was an expansion in the harvested area to 3,129 ha, totaling 5,201 tons of nuts (IBGE, 2015). In the same year, the Southern region of Brazil was responsible for $74 \%$ of the pecan harvest area, totaling 2,312ha, in which Cachoeira de Sul and Anta Gorda are the municipalities with the largest production areas. The Southeast region is the second largest Brazilian producer of pecans, with 817 ha and $26 \%$ of the harvested area, mainly in the municipalities of Dois Córregos and Mineiros do Tietê.

One of the main factors that have driven the establishment of new pecan orchards is the price paid to producers. Until 2007, the price of pecan traded at CEASA (Supply Center that promote and regulate the commercialization of fruits and vegetables) in Porto Alegre (RS) was lower than US\$ $3.00 \mathrm{~kg}^{-1}$. Thereafter, there was a strong increase in the amount paid by pecan in shell, to US\$ $4.06 \mathrm{~kg}^{-1} ; 4.26 ; 4.25 ; 4.94 ; 4.85$; 4.53 and 4.25 in the years of 2008, 2009, 2010, 2011, 2012, 2013 and 2014, respectively.

\section{Climatic requirements}

The largest producing regions of nuts in the world are located between the parallels of $25^{\circ}$ and $35^{\circ}$ latitudes North and South (BARRIOS et al., 2010). The plant is well developed in climate conditions that range from humid to dry, requiring temperatures between 24 and $30^{\circ} \mathrm{C}$ during the vegetative growth, with little variation between day and night temperatures, in order to achieve a proper development (SPARKS, 2005). During the winter, temperatures lower or equal to $7.2^{\circ} \mathrm{C}$ help to overcome the dormancy of the plants. Pecan growing regions should have a minimum of 100 chill units (WELLS, 2017). However, as winter chill accumulation increases, the heat required for spring budbreak decreases (SPARKS, 2005).

Adult pecan orchards require high levels of light for optimal growth, yield and nut quality (ÁVILA et al., 2010). When the crowns of neighboring trees reach each other, the branches located below them grow less, resulting in a lower production, due to the reduction of light incidence (WOOD \& STAHMANN, 2004). Therefore, caution regarding the density of plants used is necessary in orchard implantation. High plant densities in pecan orchards will present problems after 10 years or more, once the trees canopy will be leaning against each other, shading the branches. This shading causes a decrease in production, since the nuts are only produced on branches where the leaves intercept sunlight, in this case, the top of the plants.

The pecan trees have high water demand and periods of hydric deficit can cause the abortion of nuts. It is estimated that an adult plant uses about 129,000 liters of water during an annual cycle, with average annual yields from 18 to $22 \mathrm{~kg}$ per tree, depending on the type of soil (CALL et al., 2006).

\section{Edaphic requirements}

Pecan grows well in deep, welldrained soils, with good levels of nutrients and organic matter and good water holding capacity, providing conditions to the development of root system (CALL et al., 2006; WELLS, 2017). When establishing commercial orchards, areas with excess moisture should be avoided, since pecan trees are sensitive to poorly drained soils, which impair its growth and development. Poorly drained soils cause stress in the root system due to the lack of oxygen, leading to a reduction in the productivity and/or death of the plants. In addition to excessive moisture, pecan trees are sensitive to saline soils (GRAGEDA et al., 2011). 
Row spacing and plant density

The distribution of plants in an orchard should favor an adequate pollination, facilitate the management and help with the future thinning of the trees. The planning of a proper plant spacing is a key step, since it interferes with the number of plants per hectare and hence, the orchard implementation cost, especially by the seedlings acquisition. The definition of spacing may vary according to the region, soil fertility, cultivars and the interest of the producer (WEELS, 2017). Pecan cultivars that are susceptible to scab should be arranged in a minimum spacing of $10 \mathrm{~m} \mathrm{x}$ $10 \mathrm{~m}$ to $10 \mathrm{~m} \times 12 \mathrm{~m}$ or $15 \mathrm{~m} \times 15 \mathrm{~m}$. Pruning or thinning of plants should be applied whenever the shading of lower branches begins to occur (WOOD, 2009). According to WELLS (2017), the spacing employed in American orchards vary from extremes of $6 \times 6 \mathrm{~m}$ to $30 \times 30 \mathrm{~m}$, resulting in 278 and 11 trees per hectare, respectively. High density provides a greater productivity in the early years; however, it increases the implementation cost and requires thinning in order to avoid productivity decrease in the following years, by the shading of adjacent branches. Therefore, this is an assessment that should be performed with caution before orchard implementation.

In pecan orchards implanted in USA, condensed spacing require thinning between the $16^{\text {th }}$ and $22^{\text {nd }}$ year after planting, or when $50 \%$ of the orchard's soil is found shaded at noon (WELLS, 2017). For Brazilian conditions, thinning takes place from the $10^{\text {th }}$ year. In order to avoid shading of the pecan trees during the first 15 years, some American farmers adopt a spacing in their orchards that varies from 15 to 20 meters between plants (WELLS, 2017).

\section{Pollination}

The pecan is a monoecious plant, having separate staminate and pistillate inflorescences on the same plant; however, it has a mechanism so-called dichogamy. This means that the time of pollen release and pistil receptivity may not overlap. The dichogamy is a morphological mechanism developed by the plant to prevent self-pollination, which can cause increased endogamy, generating smaller nuts and lower kernel yield (WOOD, 2000). The type of dichogamy in pecan cultivars is not fixed and varied according to the cultivar, region, year, age and vigor of the plant. During the spring, climatic conditions influence the maturing period of the pecan inflorescences. Periods with high relative humidity and higher temperature result in an earlier maturation of the staminate inflorescences. In contrast, dry and cold periods in the spring, anticipate the maturation of the pistil inflorescences and retard the maturation of staminate inflorescences (ADRIANCE, 1931).

Despite the climatic conditions that influence the flowering pattern in pecan trees, this is also a cultivar attribute. There are pecan trees that first mature the staminate inflorescences and others the pistil inflorescences. Therefore, WOOD (2000) classified the pecan cultivars in two great categories. The first is called "Type I" or "protandrous", because the staminate structure matures first. Despite being commonly called "pollinators", the cultivars from this category also produce nuts with commercial value. It is suggested that in a commercial orchard, at least $15 \%$ of the plants must be pollinators (WELLS, 2017). For the climatic conditions from Southern Brazil, a higher percentage of pollinators are recommended. The second category is denominated "Type II" or "protogynous", because the pistil structure is the one that matures first (stigma of the female flowers become receptive before the catkins begin to shed pollen).

An adequate plant pollination in pecan commercial orchards is a factor of paramount importance for obtaining high productivity, though it often receives little attention during the planting planning. The occurrence of inadequate pollination in some years may result in a decrease in nut yield and quality (CONNER, 2012). The pollination of pecan is predominantly carried out by the wind (anemophilous) and is effective up to 49 meters between plants, with a substantial reduction in fruiting in larger spacing (CONNER, 2011; WELLS, 2017). For this reason, when setting the pollinator cultivars arrangement, one should avoid them from being too far from the producing cultivars.

Cross-pollination is necessary to achieve a maximum pecan production (WELLS, 2017), which has a greater occurrence than self-pollination. Commercial orchards must be composed of at least two pollinator cultivars, but ideally from three to four (CONNER, 2012), aiming to increase the overlapping period of pollen dehiscence and stigma receptivity (WOOD, 1996). Concerning the Southern region of Brazil, there is only one study that has assessed the period of pollination and stigma receptivity of different pecan cultivars, which was conducted by BARACUHY (1980) (Figure 1), in the town 


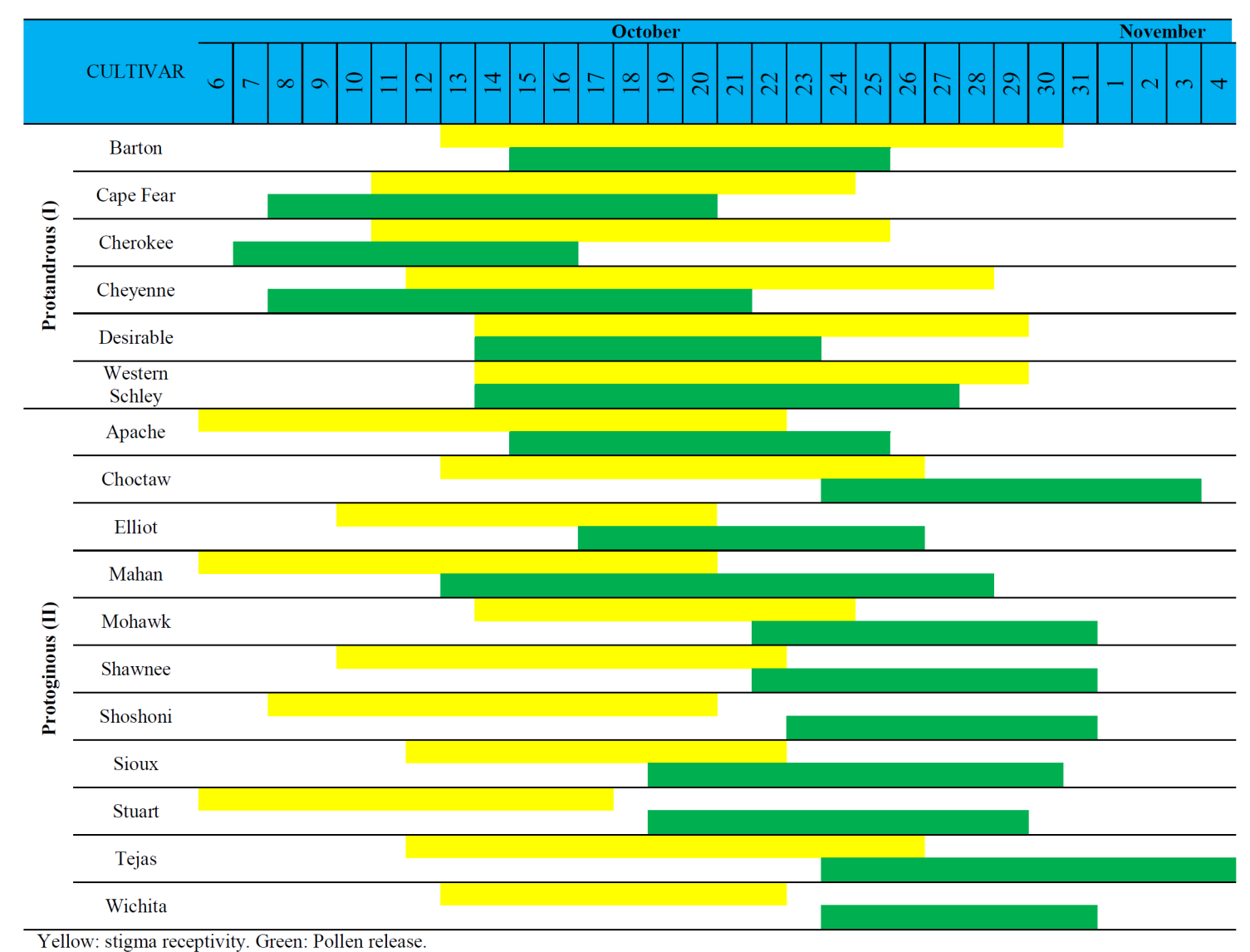

Figure 1 - Pollen shedding and stigma receptivity period of some pecan nut cultivars. Cachoeira do Sul, Brazil, 1979. Adapted from: Baracuhy (1980).

of Cachoeira do Sul (RS). This information is of utmost importance when choosing cultivars in the establishment of commercial orchards in the Brazilian Southern region.

\section{Cultivars}

In the last years, many pecan cultivars were introduced in Brazil and of these, 40 are registered at the Ministry of Agriculture, Livestock and Supply (MAPA, 2014). However, only a few are available in nurseries at commercial level, and are described in some detail in table 1. In addition, the cultivars Brooks, Caddo, Cherokee, Chetopa, Clark, Curtis, Davis, Elliott, Forkert, Giles, Gloria Grande, Jenkins, Jubilee, Kiowa, Mahan, Major, Moore, Oconee, Owens, Patrick, Pawnee, Peruque, Pitol 1, Pitol 2, Posey, Prilop of Lavaca, Sioux, Summer and Woodroof are also registered (MAPA, 2014).

\section{Propagation}

The pecan seedlings used in the orchard establishment are grafted and may be acquired with bare root or placed inside plastic containers. Rootstocks are obtained from seeds. To obtain better germination and seedling development it is recommended a stratification period before sowing, by placing the seeds for 90 days in moist sand, at $4.0^{\circ} \mathrm{C}$ (POLETTO et al., 2016). Bare root should be, preferably, transplanted in the plant's dormancy period (winter) and the seedlings in plastic containers can be transplanted at any time of the year, provided they are irrigated during water deficiency (WELLS, 2017). In Brazil, bare and covered (in plastic containers) seedlings are commercialized.

The use of adequate rootstock is a key factor in grafting, once it will influence in plant development, especially the absorption of nutrients such as potassium and zinc 
Table 1 - Main pecan cultivars available in nurseries of South Brazil production areas and its nut characteristics.

\begin{tabular}{lcccc}
\hline Cultivar & Parents & Year of obtention & Shell Thickness (mm) & Kernel Yield (\%) \\
\hline Barton & Success x Moore & 1937 & 0.43 & 57 \\
Cape Fear & Shley & 1937 & 0.72 & 52 \\
Choctaw & Success x Mahan & 1946 & 0.79 & 56 \\
Chickasaw & Brooks x Evers & 1944 & 0.64 & $35-54$ \\
Desirable & Unknown parents & 1900 & 0.68 & 51 \\
Farley & Unknown parents & 1918 & 0.99 & 51 \\
\hline Jackson & Success x Shley & 1917 & 0.98 & 52 \\
Moneymaker & Unknown parents & 1986 & 0.69 & 44 \\
Shawnee & Shley x Barton & 1949 & 0.77 & 56 \\
Stuart & Unknown parents & 1874 & 1.00 & 46 \\
Success & Unknown parents & 1901 & 0.66 & 50 \\
Shoshoni & Odom x Evers & 1972 & 50 \\
\hline
\end{tabular}

Adapted from researches of Sparks (1992); Worley et al. (1994); Wells (2017).

(THOMPSON et al., 2002). Currently, in the state of Rio Grande do Sul, the main cultivars used as rootstocks are Barton, Elliott, Jackson and Moneymaker (ACQUISITION SOURCES). The nurserymen who produce pecan seedlings have performed tests in their nurseries and choose these cultivars as rootstock, for being easier for propagation (seed germination), presents good vigor and compatibility with the scion.

\section{Nutrition of pecan trees}

The root system of pecan trees has the ability to establish a symbiotic association with mycorrhizal fungi; however, the relationship between the mycorrhizae and pecan nutrition is still understudied. The mycorrhizae that are linked to the absorption roots allow the trees to increase the root system area exploration and to optimize the absorption of $\mathrm{N}, \mathrm{P}, \mathrm{K}, \mathrm{Ca}, \mathrm{Mg}, \mathrm{Zn}$ and $\mathrm{Cu}$ from the soil, resulting in production increases (BONITO et al., 2011).

The pecan demands a lot of zinc, especially in calcareous soils (BARRIOS et al., 2012). Zinc deficiency in pecan plants can impair the chloroplast development, reduce the weight of nuts, decrease the amount of fruits produced by the branches, drastically decreasing the development of fruits and delaying nuts maturation (OJEDA-BARRIOS et al., 2014). According to SPARKS (1993), the pecan foliar concentration of $\mathrm{Zn}$ should not be lower than $50 \mathrm{mg}$ $\mathrm{kg}^{-1}$, in order to avoid the occurrence of deficiency symptoms and production reduction. In Brazilian states of Rio Grande do Sul and Santa Catarina the Zn concentration considered adequate for pecans ranges between 50 and 100 $\mathrm{mg} \mathrm{kg}^{-1}$ (SBCS, 2016). Further recommendations for the fertilization of this culture can also be found in that publication.

\section{Main pests}

The infestation of the Black margined aphid [Monellia caryella (Fitch)] causes major losses in pecan commercial orchards in the United States. A single individual, during its life cycle, is able to consume 301 joules energy from the parasitized plant (WOOD et al., 1987). Besides consuming photoassimilates and water, this pest also secretes a sugary liquid on the leaves surface, which are covered by a black mycelium of fungus (sooty mold) that grows in this condition, reducing the photosynthetic area due to the lower light incidence in the leaves.

The phylloxera (Phylloxera notabilis), a small insect that parasitizes the leaves of the pecan trees is also an important pest. Its feeding stimulates the plant to produce galls on the leaves, which appear next to the secondary veins of leaflets. Severe attacks may result in premature defoliation of the plants (DUTCHER et al., 2010). In addition to the aforementioned pests, bugs can cause damages to the growing nuts, causing punctual necrosis to the area of the kernel that was attacked, depreciating their commercial value (DUTCHER et al., 2010) and causing premature fruit drop. Occurrence of mites has also been observed during drought years. A problem for nuts producing areas of Brazil is that there are no products registered in the country to control any kind of pests that attacks this crop. 


\section{Main diseases}

The scab, caused by the fungus Fusicladium effusum (G. Winter) (syn. Cladosporium caryigenum (Ellis \& Langl.) Gottwald) is the most common disease and the one with the highest incidence in pecan crops worldwide (VANN 2012). The fungus can cause damage to leaves, petioles and in the capsule that surrounds the nut. In severe cases, damages occur in new branches and catkins, which are the staminate flowers (SMITH, 2008).

The main damage caused by this disease is the suppression of leaf development, reducing the photosynthetic area. Scab occurrence is enhanced by rainfall, high humidity and temperatures above $21^{\circ} \mathrm{C}$ (PAYNE \& SMITH, 2012). For that reason, it is required a greater attention in the major producing regions of Brazil, since they have favorable conditions for this disease development. There are pecan varieties that have higher resistance to scab, so this information is very relevant when choosing cultivars, especially in areas that present propitious settings for scab occurrence. In their study, THOMPSON \& GRAUKE (1994), listed a few pecan cultivars with different resistance degrees (Table 2). In the Southern Brazil main production areas there are no scientific data on pecan scab resistance of the cultivars adopted. However, fruit growers and experts observed greater scab resistance in Barton, Farley, Imperial, Jackson, Melhorada and Stuart cultivars. In turn, Cape Fear, Chickasaw, Importada, Mahan and
Shawne showed lower scab resistance and only produce well-filled nuts with scab management in the field (ACQUISITION SOURCES).

Likewise the pests, there are no registered products that can be used to control the diseases in pecans, to this date, in Brazil. Furthermore, the high size of the plants also hinders a homogeneous spraying of the canopy. Therefore, it is important to adopt preventive measures, such as planting in well drained areas, with good sunlight incidence, using adequate spacing and cultivars that are more tolerant or resistant.

\section{CONCLUSION}

In light of the increasing implementation of pecan orchards in Brazil, this review brings information that contributes to the adequate management, taking in consideration the particularities of this culture. There are positive prospects for pecan implementation since the nut presents essential nutraceutical properties to the human health. Moreover, it serves as an economic investment that can bring, in medium term, good returns to the farmers.

Nonetheless, a great deal of information was obtained from international literature, once there are practically no findings of scientific studies conducted with pecan in Brazil, so it is crucial that actions of research and extension be carried out in order to enhance the development of this culture.

Table 2 - Pecan nut cultivar classification in relation to scab genetic resistance, evaluated in Brownwood, Texas, in the year of 1992 , according Hunter e Roberts (1978) scale, where $5=$ higher susceptibility and $1=$ higher resistance.

\begin{tabular}{lccc}
\hline Cultivar & Classification & Cultivar & Classification \\
\hline Wichita & $5.0 \mathrm{a}^{1}$ & Barton & $1.7 \mathrm{eg}$ \\
Burkett & $5.0 \mathrm{a}$ & Kiowa & $1.7 \mathrm{eg}$ \\
Western Schley & $5.0 \mathrm{a}$ & Cape Fear & $1.7 \mathrm{eg}$ \\
Cheroke & $4.0 \mathrm{ab}$ & Choctaw & $1.7 \mathrm{eg}$ \\
Comanche & $4.0 \mathrm{ab}$ & Chickasaw & $1.5 \mathrm{eg}$ \\
Cheyene & $3.5 \mathrm{bc}$ & Curtis & $1.5 \mathrm{eg}$ \\
Mahan & $3.3 \mathrm{bd}$ & Desirable & $1.5 \mathrm{eg}$ \\
Shawnee & $3.0 \mathrm{be}$ & Stuart & $1.5 \mathrm{eg}$ \\
Pawnee & $2.5 \mathrm{cg}$ & Moreland & $1.5 \mathrm{fg}$ \\
Shoshoni & $2.5 \mathrm{cg}$ & Summer & $1.2 \mathrm{fg}$ \\
Mohawk & $2.5 \mathrm{cg}$ & Jackson & $1.0 \mathrm{~g}$ \\
Maramec & $2.5 \mathrm{cg}$ & Success & $1.0 \mathrm{~g}$ \\
Osage & $2.2 \mathrm{cg}$ & Gloria Grande & $1.0 \mathrm{~g}$ \\
\hline
\end{tabular}

${ }^{1}$ Means followed by the same letter in the column, do not differ by Duncan test $(\alpha \leq 0.05)$. Source: Thompson $\&$ Grauke (1994). 


\section{ACQUISITION SOURCES}

The authors obtained this information by speaking with the six greater pecan nurserymen that commercialize pecan seedling in the state of Rio Grande do Sul and with pecan growers in the main production areas.

\section{ACKNOWLEDGEMENTS}

The authors are grateful to Colégio Politécnico da Universidade Federal de Santa Maria (UFSM), which approved and maintain the project entitled: "Qualificação e aprimoramento de profissionais, estudantes e pessoas da comunidade em horticultura e áreas afins", process number 036877.

\section{REFERENCES}

ADRIANCE, G.W. Factors influencing fruit setting in the pecan. Botanical Gazette. v.91, n.2, p.144-166, 1931. Available from: $<$ http://www.journals.uchicago.edu/doi/pdfplus/10.1086/334136>. Accessed: Dec. 12, 2017. doi: 10.1086/334136.

ÁVILA, J.G.A. et al. Sunlight availability and nut production after removing pecan trees (Carya illinoensis). Revista Chapingo Serie Ciencias Forestales y del Ambiente, v.16, n.2, p.147-154, 2010. Available from: $<$ https://chapingo.mx/revistas/forestales/contenido. php?id articulo $=814$ ? id revistas $=3>$. Accessed: Dec. 12, 2017. doi: $10.515 \overline{4} /$ r.rchscfa. $2009 . \overline{1} 1.047$.

BARACUHY, J.B.C. Determinação do período de floração e viabilidade do pólen de diferentes cultivares de nogueira peca Carya illinoensis (Wang) K.Koch. 1980. 52f. Dissertação (Mestrado em Fitotecnica) - Curso de Pós-Graduação em Agronomia, Universidade Federal de Pelotas.

BARRIOS, D.O. et al. SWOT analysis and perspectives of pecan production in Chihuahua-Mexico. Revista Mexicana de Agronegocios, v.14, n.27, p.348-359, 2010. Available from: <http://www.redalyc.org/ articulo.oa? $\mathrm{id}=14114743006>$. Accessed: Dec. 12, 2017.

BARRIOS, D.O. et al. Zinc deficiency in field-grown pecan trees: changes in leaf nutrient concentrations and structure. Journal of the Science of Food and Agriculture, v.92, p.1672-1678, 2012. Available from: <http://onlinelibrary.wiley.com/doi/10.1002/jsfa.5530/full > Accessed: Dec. 12, 2017. doi: 10.1002/jsfa.5530.

BONITO, G. et al. Ectomycorrhizal fungal diversity in orchards of cultivated pecan (Carya illinoinensis; Juglandaceae). Mycorrhiza, v.21, n.7, p.601-612, 2011. Available from: <https://link.springer. com/article/10.1007\%2Fs00572-011-0368-0>. Accessed: Dec. 12, 2017. doi: 10.1007/s00572-011-0368-0.

CALL, R.E. et al. Pecan production guidelines for small orchards and home yards. Tucson-AZ: College of Agriculture and Life Sciences. University of Arizona. 2006. 12p.

CONNER, P.J. Optimization of in vitro pecan pollen germination. HortScience, v.46, n.4, p.571-576, 2011. Available from: $<$ http://hortsci. ashspublications.org/content/46/4/571.full>. Accessed: Dec. 12, 2017.

CONNER, P.J. Pollination Charts Revisited. The Grower Pecan, v.23, n.4, p.34-39, 2012. Available from: $<$ http://www.caes.uga.edu/content dam/caes-website/extension-outreach/commodities/pecan-breeding/ docs/papers/Pollination-Charts-Revisited.pdf> . Accessed: Dec. 12, 2017.
DOMÍNGUEZ-AVILA, J.A. et al. The pecan nut (Carya illinoinensis) and its oil and polyphenolic fractions differentially modulate lipid metabolism and the antioxidant enzyme activities in rats fed high-fat diets. Food Chemistry, v.168, p.529-537, 2015.Available from: <https:// www.sciencedirect.com/science/article/pii/S0308814614011406>. Accessed: Dec. 12, 2017. doi: 10.1016/j.foodchem.2014.07.092.

DUTCHER, J. D. et al. Integration of insect and mite management with disease and weed control in pecan production. In: CIANCIO, A.; MUKERJI, K.G. Integrated Management of Arthropod Pests and Insect Borne Diseases. 2010. Chap. 6, p.133-162.

EAGAPPAN, K.; SASIKUMAR, S. Therapeutic effects of nuts in various diseases. International Journal of Recent Scientific Research, v.5, n.1, p.190-197, 2014. Available from: <http://recentscientific.com/ sites/default/files/Download_812.pdf $>$. Accessed: Dec. 12, 2017.

FRONZA, D.; HAMANN, J.J. Técnicas para o cultivo da nogueirapecã. Santa Maria - RS: Universidade Federal de Santa Maria, Colégio Politécnico, Núcleo de Fruticultura Irrigada. 2016. 402p.

GRAGEDA, J.G. et al. Soil salinity in pecan orchards Carya illinoinensis (Wangenh.) K. Koch. Biotecnia, v.13, n.3, p.22-27, 2011. Available from: $<$ https://biotecnia.unison.mx/index.php/biotecnia/article/view/95/88>. Accessed: Dec. 12, 2017. doi: 10.18633/bt.v13i3.95.

IBGE. Instituto brasileiro de geografia e estatística. Produção Agrícola Municipal. 2015. Available from: <https://sidra.ibge. gov.br/Tabela/1613\#resultado>. Accessed: Mar. 08, 2017.

INC (International Nut \& Dried Fruit). Global Statistical Review 2014-2015. Espanha. 2015. 76p.

LÓPEZ, R.R. et al. Analysis of profitability of pecan walnut crop in costa de Hermosillo. Revista Mexicana de Agronegocios, v.18, n.34, p.872-882, 2014. Available from: <http://www.redalyc.org/ articulo.oa?id=14131514021>. Accessed: Dec. 12, 2017.

MAPA. Ministério da Agricultura, Pecuária e Abastecimento. Registro Nacional de Cultivares. Brasília, 2014. Available from: $<$ http://extranet.agricultura.gov.br/php/snpc/cultivarweb/cultivares_ registradas.php>. Accessed: Ago. 24, 2016.

MURAYAMA, S. Fruticultura. Campinas: Instituto Campineiro de Ensino Agrícola, 1986. $2^{\text {a }}$ ed. 385 p.

OJEDA-BARRIOS, D.L. et al. Foliar Fertilization with Zinc in Pecan Trees. HortScience, v.49, n.5, p.562-566, 2014. Available from: $<$ http://hortsci.ashspublications.org/content/49/5/562.full $>$. Accessed: Dec. 12, 2017.

ORTIZ, E.R.N.; CAMARGO, L.E.A. Doenças da Nogueira Pecan. In: KIMATI, H. et al. (Eds.). Manual de fitopatologia: doenças das plantas cultivadas. 4. ed. São Paulo: Agronômica Ceres, 2005. p.501-505.

PAYNE, A.; SMITH, D.L. Development and Evaluation of Two Pecan Scab Prediction Models. Plant Disease, v.96, p.13581364, 2012. Available from: <https://apsjournals.apsnet.org/doi/ pdfplus/10.1094/PDIS-03-11-0202-RE>. Accessed: Dec. 12, 2017. doi: 10.1094/ PDIS-03-11-0202-RE.

POLETTO, T. et al. Dormancy overcome and seedling quality of pecan in nursery. Ciência Rural, v.46, n.11, p.1980-1985. 2016. Available from: <http:/www.scielo.br/scielo.php?script=sci_arttext\&pid=S010384782016001101980\&lng=en\&tlng=en>. Accessed: Dec. 12, 2017. doi: $10.1590 / 0103-8478 \mathrm{cr} 20150835$. 
SBCS - Sociedade Brasileira de Ciência do Solo. Manual de adubação e de calagem para os Estados do Rio Grande do Sul e de Santa Catarina / Sociedade Brasileira de Ciência do Solo. Comissão de Química e Fertilidade do Solo. -11. ed. Porto Alegre. 2016. 375 p.

SMITH, D.L. Reminders about Pecan scab and the advisory in Oklahoma. Oklahoma Pecan Growers Association, v.49, n.3. p.10-11, 2008 .

SPARKS, D. Adaptability of pecan as a species. Hortscience, v.40, n.5, p.1175-1189, 2005. Available from: $<$ http://hortsci.ashspublications. org/content/40/5/1175.full.pdf+html $>$. Accessed: Dec. 12, 2017.

SPARKS, D. Pecan cultivars: the orchard's foundation. University of Georgia. 1992. 446p.

SPARKS, D. Threshold leaf levels of zinc that influence nut yield and vegetative growth in pecan. Hortscience, v.28, n.11, p.11001102, 1993. Available from: <http://hortsci.ashspublications.org/ content/28/11/1100.full.pdf + html $>$. Accessed: Dec. 12, 2017.

THOMPSON, T.E. et al. Rootstock influence on tree performance. In Texas Pecan Grow. Assoc., 2002. Proceeding... ed.70. 2002, p.20-24.

THOMPSON, T.E.; GRAUKE, L.J. Genetic resistance to scab disease in pecan. Hortscience, v.29, n.9. p.1078-1080, 1994. Available from: $\quad<$ http://hortsci.ashspublications.org/content/29/9/1078.full. pdf + html $>$. Accessed: Dec. 12, 2017.

USDA (National Agricultural Statistics Service). Noncitrus Fruits and Nuts 2016 Summary. Pecan Bearing Acreage, Yield, Production, Price, and Value - States and United States: 2014-2016. p. 103-105, (June 2017). Available from: <http://usda.mannlib.cornell. edu/MannUsda/viewDocumentInfo.do?documentID=1113>. Accessed: Sep. 08, 2017.

VANN, S. Home Pecan Diseases and Control. University of Arkansas: United States Department of Agriculture, and County Governments Cooperating. 2012. 2p. (FSA7540).

WAKELING, L.T. et al. Composition of pecan cultivars Wichita and Western Schley [Carya illinoinensis (Wangenh.) K. Koch] grown in
Australia. Journal of agricultural and food chemistry, v.49, n.3, p.1277-1281, 2001. Available from: <http://pubs.acs.org/doi/ abs/10.1021/jf000797d >. Accessed: Dec. 12, 2017. doi: 10.1021/ jf000797d.

WELLS, L. Southeastern Pecan Grower's Handbook. University of Georgia. 2017. 236p.

WOOD, B.W. Cross-pollination within pecan orchards. HortScience, v.31, n.4, p.583, 1996. Available from: $<$ http://hortsci.ashspublications. org/content/31/4/583.4.full.pdf + html? sid $=0 \mathrm{~d} 2 \mathrm{c} 83 \mathrm{f0}-459 \mathrm{e}-48 \mathrm{ad}-\mathrm{a} 0 \mathrm{ca}-$ 1baad12cfbee>. Accessed: Dec. 12, 2017.

WOOD, B.W. Mechanical hedge pruning of pecan in a relatively low-light environment. HortScience, v.44, n.1, p.6872, 2009. Available from: <http://hortsci.ashspublications.org/ content/44/1/68.full>. Accessed: Dec. 12, 2017.

WOOD, B.W. et al. Energy drain by three pecan aphid species (Homoptera: Aphididae) and their influence on in-shell pecan production. Environmental Entomology, v.16, n.5, p.1045-1056, 1987. Available from: <https://academic.oup.com/ee/article-abstr act/16/5/1045/466022?redirectedFrom=fulltext $>$. Accessed: Dec. 12, 2017. doi: dx.doi.org/10.1093/ee/16.5.1045.

WOOD, B.W. Pollination characteristics of pecan trees and orchards. HortTechnology, v.10, n.1, p.120-126, 2000. Available from: <http://horttech.ashspublications.org/content/10/1/120.full. pdf + html $>$. Accessed: Dec. 12, 2017.

WOOD, B.W.; STAHMANN, D. Hedge pruning pecan HortTechnology, v.14, n.1, p.63-72, 2004. Available from: $<\mathrm{http}: / /$ horttech.ashspublications.org/content/14/1/63.full.pdf + html $>$. Accessed: Dec. 12, 2017.

WORLEY, R.E. Pecan production. In: SANTERRE, C.H. Pecan Technology. Chapman \& Hall Edition, 1994. Chap. 2, p.12-38.

ZHANG, R. et al. Pecan production in China. Scientia Horticulturae, v.197, p.719-727, 2015. Available from: <https:// www.sciencedirect.com/science/article/pii/S0304423815302648>. Accessed: Dec. 12, 2017. doi: 10.1016/j.scienta.2015.10.035. 